\title{
Functional redundancy of genes for sulphate activation enzymes in Rhizobium Sp. BR816
}

\author{
T. Laeremans, ${ }^{1,2}$ N. Coolsaet, ${ }^{2}$ C. Verreth, ${ }^{2}$ C. Snoeck, ${ }^{2}$ N. Hellings, ${ }^{2}$ \\ J. Vanderleyden ${ }^{2}$ and E. Martínez-Romero ${ }^{1}$
}

Author for correspondence: J. Vanderleyden. Tel: +32163296 79. Fax: +3216321966.

e-mail: Jozef.Vanderleyden@agr.kuleuven.ac.be

1 Departamento de Genética Molecular, Centro de Investigación sobre Fijación de Nitrógeno, Universidad Nacional Autónoma de México, Ap. 565-A Cuernavaca, Morelos, Mexico

2 F. A. Janssens Laboratory of Genetics, Kardinaal Mercierlaan 92, B-3001 Heverlee, Belgium

\begin{abstract}
The broad-host-range, heat-tolerant Rhizobium strain BR816 produces sulphated Nod metabolites. Two ORFs highly homologous to the Sinorhizobium meliloti nodPQ genes were isolated and sequenced. It was found that Rhizobium sp. BR816 contained two copies of these genes; one copy was localized on the symbiotic plasmid, the other on the megaplasmid. Both nodP genes were interrupted by insertion of antibiotic resistance cassettes, thus constructing a double nodP1P2 mutant strain. However, no detectable differences in Nod factor TLC profile from this mutant were observed as compared to the wild-type strain. Additionally, plant inoculation experiments did not reveal differences between the mutant strain and the wild-type. It is proposed that a third, functionally homologous locus complements mutations in the Nod factor sulphation genes. Southern blot analysis suggested that this locus contains genes necessary for the sulphation of amino acids.
\end{abstract}

Keywords: Nod factor, TLC, sulphate activation, nodPQ, Rhizobium sp. BR816

\section{INTRODUCTION}

Symbiotic nitrogen fixation as an economical and environmentally friendly alternative to chemical synthesis of nitrogen fertilizers is an important feature of the symbiosis between legume plants and bacteria of the genera Rhizobium, Bradyrhizobium, Sinorhizobium and Azorbizobium. As a result of the recognition between compatible plant and bacterial symbionts, new plant organs known as nodules emerge. The symbiotic bacterial form, the bacteroid, synthesizes nitrogenase, an enzymic complex that converts atmospheric nitrogen into ammonia, which is directly available for plant nitrogen metabolism (reviewed by Mylona et al., 1995).

During the early stages of the infection, reciprocal signal exchange occurs between the two symbionts. The bacterial NodD sensor protein responds to the presence of flavonoid molecules released by the plant and functions as the main positive regulator of the expression of the structural nodulation genes (nod, nol, noe) (Mulligan \& Long, 1985). The products of the nod genes

\footnotetext{
Abbreviations: APS, adenosine 5'-phosphosulphate; LCO, lipo-chitin oligosaccharide; NF, Nod factor; PAPS, 3'-phosphoadenosine 5'-phosphosulphate; Ap, ampicillin; Gm, gentamycin; Km, kanamycin; Nal, nalidixic acid; Sm, streptomycin; Sp, spectinomycin; Tc, tetracycline.

The GenBank accession number for the sequence reported in this paper is U59507.
}

generate the proteins involved in the synthesis and transport of mixtures of bacterial signal molecules, i.e. the Nod factors, also called lipo-chitin oligosaccharides (LCOs). Physiological effects of the LCOs on their leguminous host plants include induction of root hair curling, formation of pre-infection threads, division of cortical root cells and, in some cases, even the formation of nodule-like structures (Truchet et al., 1991; reviewed by Spaink, 1996). The LCOs consist of a backbone of three to six 1,4- $\beta$-linked $N$-acetylglucosamine units linked to a fatty acid group at the non-reducing end, which also contains additional strain-specific substituents.

The enzymes necessary for the production of the LCO backbone are encoded by the nod $A B C$ genes found in all nodulating rhizobial strains. These genes are referred to as 'common' nod genes (Kondorosi, 1991), although recently Ritsema et al. (1996) found that the replacement of the Rhizobium leguminosarum bv. viciae nodA by its Bradyrhizobium japonicum homologue resulted in the loss of Vicia nodulation. Additionally, Debellé et al. (1996) proved that the 'common' NodA protein of Sinorbizobium (previously Rhizobium) meliloti contributes to its host range determination.

The host-specific nodulation genes are responsible for the side groups exclusively encountered on the two extreme glucosamine residues of the LCO core molecule. 
On the non-reducing end, the nodS (Geelen et al., 1993), nodL (Downie, 1989) and nodU (Jabbouri et al., 1995) genes have been shown to be responsible for $N$-methyl (Price et al., 1992), O-acetyl (Carlson et al., 1993) or Ocarbamoyl (Price et al., 1992) substitutions, respectively. On the reducing end, sugar modifications such as a fucosyl residue (Price et al., 1992; Sanjuan et al., 1992), an arabinosyl residue (Mergaert et al., 1993) or a mannosyl moiety (Folch-Mallol et al., 1996) can be present (for an overview of Nod factor structures and nodulation genes, see Dénarié et al., 1996). Other reducing end side decorations include an $\mathrm{O}$-acetylation (Price et al., 1992) and an O-sulphation, the latter modification either directly linked to the $\mathrm{C} 6$ of the nonreducing sugar (for $S$. meliloti, see Lerouge et al., 1990) or on a methylfucosyl group (for Rbizobium sp. NGR234, see Price et al., 1992). For sulphate modification of the former type, the involvement of three genes has been reported in $S$. meliloti.nodP and nodQ together encode an ATP sulphurylase (Schwedock \& Long, 1990), whereas nodQ alone additionally encodes an adenosine $5^{\prime}$-phosphosulphate (APS) kinase (Schwedock et al., 1994). The NodPQ enzyme complex activates the inorganic sulphate source via APS to 3 '-phosphoadenosine $5^{\prime}$-phosphosulphate (PAPS). Finally, NodH catalyses the transfer of the activated sulphate group from its donor PAPS directly onto the 6-O-position of the reducing end glucosamine unit (Schultze et al., 1995; Ehrhardt et al., 1995). Nod factor (NF) sulphation genes were also isolated from Rhizobium tropici type A and B reference strains (Laeremans et al., 1996 and FolchMallol et al., 1996, respectively) and from Rhizobium sp. N33 (Cloutier et al., 1996). In these three strains the NF sulphation genes are organized in one nodHPQ operon whereas in S. meliloti, nodH and nodPQ are separated by nodEF and nod $G$ (Debellé \& Sharma 1986; Faucher et al., 1988; Cervantes et al., 1989). For nodulation of alfalfa by $S$. meliloti, the sulphated NF is indispensable (Roche et al., 1991; Truchet et al., 1991), possibly because the sulphate moiety protects the NF against plant-chitinase degradation (Schultze et al., 1993; Staehelin et al., 1994).

Previously, we isolated the nodHPQ operon from $R$. tropici strain CFN299 and showed that the sulphate substituent was detrimental for nodulation of highnitrogen-fixing bean cultivars (Laeremans et al., 1996). Since we are interested in the role of the sulphate group for bean nodulation, we isolated the nodPQ genes from R hizobium sp. BR 816, a broad-host-range bacterium related to $S$. meliloti. BR 816 is a heat-tolerant tropical strain originally isolated from Leucaena leucocephala nodules that also nodulates common bean (Hungria et al., 1993). We show that two copies of nodPQ are present, and give evidence that a third locus can provide an activated sulphate source for NF sulphation.

\section{METHODS}

Bacterial cultures. The bacterial strains and plasmids used in this work are listed in Table 1. Rhizobium strains were grown on peptone-yeast (PY) medium (Beringer, 1974) at $29^{\circ} \mathrm{C}$ with nalidixic acid (Nal; $\left.30 \mathrm{mg} \mathrm{l}^{-1}\right)$ and supplemented with the following antibiotics $\left(\mathrm{mg} \mathrm{l}^{-1}\right)$ when necessary: tetracycline $(\mathrm{Tc}, 5)$; spectinomycin $(\mathrm{Sp}, 100)$; streptomycin $(\mathrm{Sm}, 100)$; and kanamycin $(\mathrm{Km}, 50)$. Escherichia coli strains were grown in Luria-Bertani medium (Sambrook et al., 1989) at $37^{\circ} \mathrm{C}$ with the following antibiotics added when required: Tc (10); ampillicin (Ap, 100); Sp (100); Sm (100); gentamycin (Gm, $25)$; and $\mathrm{Km}(25)$.

DNA manipulations. Isolation and cloning of plasmid or cosmid DNA was performed using the protocols described by Sambrook et al. (1989). Total genomic DNA of Rhizobium strains was isolated using a DNA/RNA Isolation Kit (USB) according to the manufacturer's instructions. Analysis of plasmid contents of Rhizobium sp. BR816 was carried out on horizontal agarose gels as described by Géniaux et al. (1995). PCR using internal nodP primers P1 and P2 was performed as described previously (Laeremans et al., 1996). PCR fragments were directly cloned in the pMOSBlue vector (Amersham). Bacterial triparental matings were done according to van Rhijn et al. (1993).

Southern hybridization. Southern-blotted DNA on positively charged nylon membranes (Boehringer Mannheim) was hybridized with non-radioactive digoxigenin-labelled probes using the DIG Labelling and Detection Kit (Boehringer Mannheim) following the manufacturer's protocol. Hybridizations were always performed under high-stringency conditions unless otherwise stated. For high-stringency conditions we (pre-)hybridized membranes at $68^{\circ} \mathrm{C}$ and washed them twice for $5 \mathrm{~min}$ at room temperature in $2 \times$ SSC (a stock solution of $20 \times$ SSC contains $3 \mathrm{M} \mathrm{NaCl}, 0.3 \mathrm{M}$ sodium citrate; $\mathrm{pH} 7) / 0.1 \%$ SDS and then at $68{ }^{\circ} \mathrm{C}$ in $0.1 \times \mathrm{SSC} / 0.1 \%$ SDS (twice for $15 \mathrm{~min}$ ). For hybridizations under lowstringency conditions, the (pre-) hybridization temperature was lowered to $60^{\circ} \mathrm{C}$ and the second washing step was performed at $60^{\circ} \mathrm{C}$ in $0.5 \times \mathrm{SSC} / 0.1 \% \mathrm{SDS}$, also twice for 15 min. The detection of hybridizing DNA fragments was performed as indicated by the manufacturer.

Sequence determination and analysis. DNA fragments were cloned in the pUC18/19 vectors and the sequence was determined on an ALF DNA sequencer (Pharmacia) using the M13 reverse and universal primers as previously described (Laeremans et al., 1996). Both strands were completely sequenced. We analysed the sequencing data using the PC/GENE software (IntelliGenetics) and the GCG software package (version 8.0.1, 1994; University of Wisconsin).

Insertion mutagenesis. For construction of nodP and nodQ insertion mutants, vectors pJQ200SK and pJQ200mp18 were used. These vectors allow positive selection of double homologous recombinants on sucrose $(5 \%)$-containing media due to the presence of the Bacillus subtilis $s a c B$ gene. Firstly, pJQ200SK was adapted by eliminating the unique SacI restriction site (Laeremans et al., 1996). To obtain the Rhizobium sp. BR816 nodP1 mutant, the 1063 bp XbaI-PstI fragment containing the nodP1 $5^{\prime}$ region (see Fig. 3) was cloned into the $\mathrm{PJQ} 200 \mathrm{SK}$ derivative from which the unique SacI restriction site had previously been eliminated. For mutagenesis, the $\mathrm{Km}$ resistance cassette of pUC-4K was used. This cassette was isolated as a BamHI restriction fragment and cloned into the BamHI site of pIC20-R (Laeremans et al., 1996). Subsequently, the $\mathrm{Km}$ resistance cassette cloned in this vector was obtained as a SacI fragment and cloned into the unique $S a c$ site of BR816 nodP1 DNA. The construct obtained was mated into the wild-type strain BR816. We hybridized total genomic DNA from Km-resistant, $\mathrm{Gm}$-sensitive colonies with the BR 816 nodP1 gene and the $\mathrm{Km}$ resistance cassette to 
Table 1. Bacterial strains and plasmids

\begin{tabular}{|c|c|c|}
\hline Strain or plasmid & Relevant characteristics & Source or reference \\
\hline \multicolumn{3}{|l|}{ Strains } \\
\hline \multicolumn{3}{|l|}{ Rbizobium sp. } \\
\hline BR816 & Broad-host-range Rhizobium isolated from Leucaena leucocephala & Hungria et al. (1993) \\
\hline CFNE205 & $\mathrm{Km}^{\mathrm{r}} \mathrm{NodP}^{-}$mutant of BR 816 & This study \\
\hline CFNE206 & $\mathrm{Sp} / \mathrm{Sm}^{\mathrm{r}}$ NodP2Q2 deletion mutant of BR816 & This study \\
\hline CFNE200 & $\mathrm{Km}^{r} \mathrm{NodP}^{-}$mutant of $R$. tropici CFN299 & Laeremans et al. (1996) \\
\hline \multicolumn{3}{|l|}{ Plasmids } \\
\hline pVK82 & pVK100 carrying the BR 816 nodP1Q1 genes & This study \\
\hline pVK100 & IncP $\mathrm{Km}^{\mathrm{r}} \mathrm{Tc}^{\mathrm{r}}$ broad-host-range cosmid & Knauf \& Nester (1982) \\
\hline BR VIID9 & pLAFR1 carrying the BR816 nodP2Q2 genes & This study \\
\hline pJQ200SK & B. subtilis $\mathrm{SacB}$-containing suicide vector, $\mathrm{Gm}^{\mathrm{r}}$ & Quandt \& Hynes (1993) \\
\hline pJQ200mp 18 & $\begin{array}{l}\text { B. subtilis } S a c B \text {-containing suicide vector, } \mathrm{Gm}^{\mathrm{r}} \text {, with the pUC18 multiple } \\
\text { cloning site }\end{array}$ & Quandt \& Hynes (1993) \\
\hline pLAFR 1. & IncP Tcr ${ }^{r}$, broad-host-range cosmid & Friedman et al. (1982) \\
\hline pUC-4K & Vector containing $\mathrm{Km}$ resistance cassette & Pharmacia Biotech \\
\hline pIC20-R & $\mathrm{Ap}^{\mathrm{r}}$ cloning vector derived from pUC19 & Marsh et al. (1984) \\
\hline pMOSBlue & $\mathrm{Ap}^{\mathrm{r}}$ cloning vector, suitable for direct cloning of PCR fragments & Amersham \\
\hline pMOSP1Q1C & 950 bp internal nodP1Q1 PCR fragment of BR816 cloned in pMOSBlue & This study \\
\hline pSmUC & Vector carrying an $\mathrm{Sm} / \mathrm{Sp}$ resistance cassette & Murillo et al. (1994) \\
\hline pIC20: $\mathrm{Km}$ & pUC-4K Km resistance cassette cloned in the BamHI site of pIC20-R & Laeremans et al. (1996) \\
\hline
\end{tabular}

confirm the expected hybridization profile of the insertion. One BR816 nodP1 mutant (CFNE205) was retained for TLC characterization.

For the construction of the Rhizobium sp. BR816 nodP1P2 double mutant, we first cloned a $950 \mathrm{bp}$ R hizobium sp. BR 816 nodP2 PCR fragment, obtained with primers P1 (Laeremans $e t$ al., 1996) and the primer Q1C, 5' ACAGTCGCCCGATCARGGTCGATTTGCCGTC 3' (derived from the sequenced BR816 nodQ1 copy) into the pMOSBlue vector (Amersham). We then ligated the $2.2 \mathrm{~kb}$ HindIII fragment from $\mathrm{pSmUC}$ containing the $\mathrm{Sp} / \mathrm{Sm}$ resistance cassette, previously blunted by using Klenow polymerase, into the unique EcoRV restriction site of the nodP2 PCR fragment. Finally, we ligated the resulting $3 \cdot 1 \mathrm{~kb} X b a \mathrm{I}-\mathrm{Bam} \mathrm{HI}$ nodP $2:: \mathrm{Sp} / \mathrm{Sm}$ fragment in pJQ200SK. This construct was conjugated into CFNE205 to obtain the double Rhizobium sp. BR816 nodP1P2 mutant (CFNE207). By hybridization with the nodP2 gene and the $\mathrm{Sp} / \mathrm{Sm}$ resistance cassette, the insertion of the cassette was demonstrated.

The single BR816 nodQ2 mutant was constructed as follows. By hybridization of a BR816 genome library, previously cloned in the EcoRI site of cosmid pLAFR1 (P. van Rhijn \& J. Vanderleyden, unpublished data) with the $1.5 \mathrm{~kb}$ Pst $\mathrm{I}$ fragment of BR816 nodP1Q1 (Fig. 3) one positive clone, BRVIID9, was isolated that contained a $12 \mathrm{~kb}$ EcoRI fragment. A $1.7 \mathrm{~kb} S p h \mathrm{I}$ subfragment containing part of nodP2 and nodQ2 was cloned into pIC20-R and the insert was cut out with restriction enzymes BglII and PstI and subsequently cloned into BamHI/PstI-digested pJQ200mp18. A nodQ2 internal 300 bp SalI fragment, located around $100 \mathrm{bp}$ from the nodQ2 start codon, was then exchanged for a SalI restriction fragment containing the $\mathrm{Sp} / \mathrm{Sm}$ resistance cassette. CFNE206 was obtained by conjugating the resulting construct into BR816 followed by sucrose selection for double homologous recombinants. The insertion of the resistance cassette into the nodP2Q2 locus was demonstrated by hybridization of CFNE206 total DNA with the $\mathrm{Sp} / \mathrm{Sm}$ resistance cassette and the nodP2Q2 locus.

Radiolabelling and detection of Nod metabolites by reversephase TLC. We radiolabelled NFs in vivo by a slightly modified version of the protocol of Mergaert et al. (1993). Overnight cultures of Rbizobium strains were inoculated in $1 \mathrm{ml}$ liquid PY medium $\left(\mathrm{OD}_{600}\right.$ of $\left.0 \cdot 1\right)$ and pre-incubated for $1 \mathrm{~h}$ before supplementing when necessary with apigenin at a final concentration of $10 \mu \mathrm{M}$. Finally, the radioactive label was added $2 \mathrm{~h}$ after apigenin induction: $40 \mu \mathrm{Ci}(1.5 \mathrm{MBq})\left[{ }^{35} \mathrm{~S}\right] \mathrm{sul}-$ phate or $25 \mu \mathrm{Ci}(0.9 \mathrm{MBq})\left[2-{ }^{14} \mathrm{C}\right]$ acetic acid, as sodium salt, and the cells labelled for $15 \mathrm{~h}$. The cell suspension was extracted twice with $500 \mu \mathrm{l}$-butanol and washed with ethyl acetate. The solution was vacuum-dried and samples were applied to reverse-phase TLC plates (RP- $18 \mathrm{~F}_{254} \mathrm{~s}$, Merck). We used $\mathrm{H}_{2} \mathrm{O} /$ acetonitrile $(1: 1, v / v)$ as the mobile phase. The radioactive compounds were visualized by autoradiography using Hyperfilm $\beta$ max (Amersham) after $4 \mathrm{~d}$ of exposure.

Nodulation assays. Seeds of the high-nitrogen-fixing Phaseolus vulgaris N-8-116 cultivar were surface-sterilized and germinated as described by Martínez et al. (1985). Plant nodulation assays were performed as described by Laeremans et al. (1996). For each inoculation, three different plant 
supports were used, mixed with $120 \mathrm{ml}$ Fahreus medium in $250 \mathrm{ml}$ flasks and subsequently sterilized: vermiculite, agar $(0.75 \%)$ or cotton $(7 \mathrm{~g})$. To verify the identity of the bacteria, nodules from each inoculation treatment were surface-sterilized for $3 \mathrm{~min}$ in sodium hypochlorite, bacteria were extracted and resistance to antibiotics was determined.

\section{RESULTS AND DISCUSSION}

\section{Rhizobium sp. BR816 Nod metabolites are sulphated}

To determine whether Rhizobium sp. BR816 produced sulphated NFs, we radiolabelled apigenin-induced cell cultures with $\left[{ }^{14} \mathrm{C}\right]$ acetate or $\left[{ }^{35} \mathrm{~S}\right]$ sulphate. Two methods of NF isolation and radiolabelling were used. We could not detect any ${ }^{14} \mathrm{C}$-labelled metabolites from apigenin-induced Rhizobium sp. BR816 cells following the method described by Laeremans et al. (1996) for the isolation of $R$. tropici CFN299 NFs from the induced cell supernatants. Rhizobium sp. BR816 probably excretes very small quantities of NFs, as has been reported previously for Rhizobium leguminosarum bv. trifolii by Orgambide et al. (1995). For other rhizobia such as $R$. tropici (Poupot et al., 1993; Laeremans et al., 1996) and Rhizobium etli (Poupot et al., 1995a) much higher amounts of NFs are excreted and detectable amounts of NF from both strains could be isolated by using only the cell supernatant of flavonoid-induced cultures. Therefore we tried the protocol published by Mergaert et al. (1993), using the total cell cultures instead of the cell supernatants only. After separation of the BR816 NFs

(a)

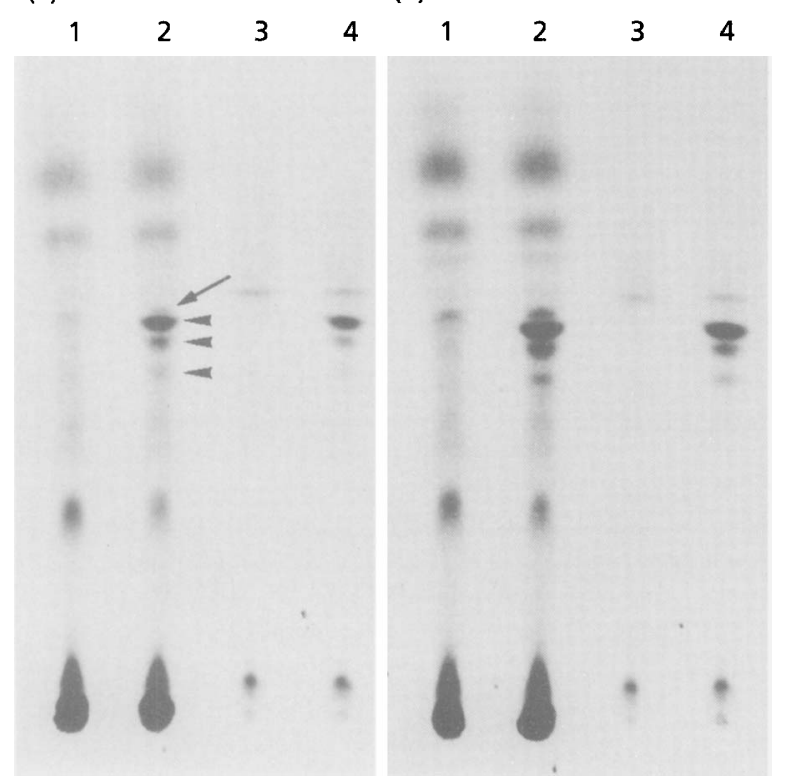

Fig. 1. Autoradiogram of a reverse-phase TLC profile of butanol extracts of radioactively labelled Rhizobium sp. BR816 (a) and CFNE207 (b). Lanes 1 and $2,{ }^{14} \mathrm{C}$-labelled; lanes 3 and 4, ${ }^{35}$ S-labelled. Lanes 1 and 3 , non-induced; lanes 2 and 4 , apigenin-induced. Putative sulphated and non-sulphated NFs are indicated with arrowheads and an arrow, respectively.

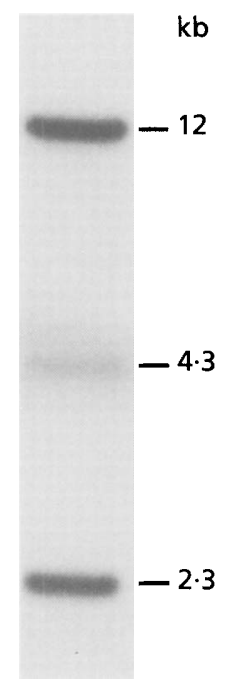

Fig. 2. Autoradiogram of Southern-blotted EcoRI-digested genomic DNA of Rhizobium sp. BR816 probed against a $S$. meliloti internal nodPQ gene fragment.

on reverse-phase TLC plates (Fig. 1a), we could distinguish at least three apigenin-induced ${ }^{14} \mathrm{C}$-labelled metabolites, which were all sulphated. A possible fourth, differently migrating, flavonoid-induced metabolite was only ${ }^{14} \mathrm{C}$-labelled. Additional Nod metabolites, not detectable by this protocol due to their low amounts, may also have been present.

\section{Isolation of the Rhizobium sp. BR816 nodP1Q1 genes}

Since all bacteria that produce sulphated NFs seem to possess nodPQ genes for sulphate activation, we looked for homology to these genes in Rhizobium sp. BR816. An EcoRI genomic DNA digest of strain BR816, hybridized with an internal $S$. meliloti nodPQ fragment under low-stringency conditions, revealed the presence of two fragments with estimated sizes of 12 and $2 \cdot 3 \mathrm{~kb}$, respectively. An additional $4.3 \mathrm{~kb} E c o$ RI DNA fragment hybridized but at low intensity (Fig. 2). When we used a 450 bp fragment, obtained by PCR on BR 816 total DNA as the template using primers P1 and P2 (Laeremans $e t$ al., 1996), an identical hybridization pattern was obtained except that the $4.3 \mathrm{~kb}$ EcoRI DNA fragment no longer hybridized (data not shown). Partial sequencing of the cloned $450 \mathrm{bp}$ PCR fragment (P1-P2) revealed high homology to an internal $S$. meliloti nodP fragment (data not shown). We therefore considered that $R h_{i-}$ zobium sp. BR816 contained at least two nodPQ copies.

By hybridization of a Rhizobium sp. BR816 plasmid library (van Rhijn et al., 1996) cloned in the EcoRI site of pVK100, against the internal BR816 nodP PCR fragment, we isolated several cosmids containing the $2.3 \mathrm{~kb}$ EcoRI fragment. One cosmid clone, pVK82, was retained for further experiments. It was used to subclone the $8 \mathrm{~kb} B a m \mathrm{HI}$ fragment with the complete nodPQ 


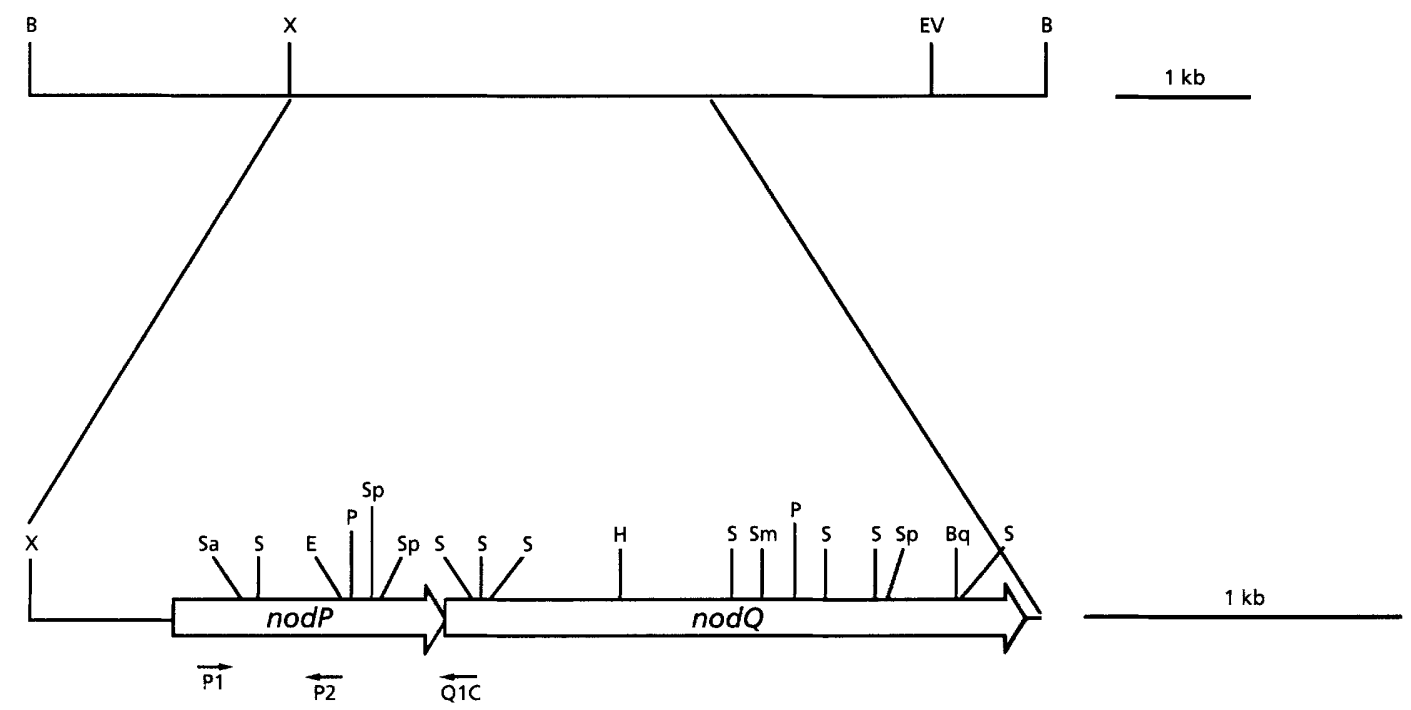

Fig. 3. Physical and genetic map of the BR816 nodP1Q1 region. Restriction sites: $B, B a m H I ; X, X b a l ; E V, E c o R V ;$ Sa, Sacl; S, Sall; E, EcoRl; P, Pstl; Sp, Sphl; H, HindIII; Sm, Smal; Bg, Bg/ll. Arrows below the map show positions of primers P1, P2 and Q1C.

homologous region and its physical map was determined (Fig. 3).

\section{Sequence determination and analysis of nodP1Q1}

We sequenced a DNA section of $3282 \mathrm{nt}$ from the $8 \mathrm{~kb}$ Bam HI fragment (Fig. 3) and found two putative ORFs showing significant homology to S. meliloti, Azospirillum brasilense, $R$. tropici, and Rhizobium sp. N33 nodP and nodQ genes. We localized the putative start codon of $\operatorname{nodP1}$ at 473 (numbers refer to the submitted GenBank sequence, U59507), preceded by a possible ribosome-binding site, GGGG, at 462. The stop codon of nodP1 (1369) overlaps the start codon of nodQ1 by one base as was found for the nodPQ genes of $S$. meliloti (Cervantes et al., 1989; Schwedock \& Long, 1989), A. brasilense (Vieille \& Elmerich, 1990) and R. tropici (Folch-Mallol et al., 1996; Laeremans et al., 1996) strains. The arctic Rhizobium sp. N33 is the only exception identified to date in which two cytosine residues separate the stop codon of nodP and the start codon of nodQ (Cloutier et al., 1996). The BR816 nodQ1 stop codon is localized at position 3271 . The putative nodQ1 ribosome-binding site (GAGG) and start codon are separated by $10 \mathrm{nt}$. We found an additional putative $16 \mathrm{~S}$ rRNA interaction site for nodP1 (CTCTT) and nodQ1 (TCT) 2 and $5 \mathrm{nt}$ downstream of their start codons, respectively (Petersen et al., 1988). nodP1 and nodQ1 are 900 and $1905 \mathrm{nt}$ long, respectively. The $\mathrm{G}+\mathrm{C}$ content for nodP1 was $61 \mathrm{~mol} \%$ and for nodQ1 $65 \mathrm{~mol} \%$. BR816 NodP1Q1 shows highest homology to $S$. meliloti NodPQ, supporting the close phylogenetic relation between $S$. meliloti and Rhizobium sp. BR 816 based upon the nucleotide sequence of $16 \mathrm{~S}$ rRNA gene fragments (Hernández-Lucas et al., 1995). Table 2 shows the homologies between the deduced amino acid sequences of the known nodP and
nodQ genes and the cysDNC genes from E. coli. Rhizobium sp. BR 816 is more distantly related to the tropical broad-host-range strain $R$. tropici CFN299, although both strains have common characteristics such as a sulphated Nod factor and overlapping host ranges (Hernández-Lucas et al., 1995).

We identified a GTP-binding site in the amino-terminal half of BR816 NodQ1 (GxxxxGK, DxxG and NKxD; Dever et al., 1987) while in the carboxy-terminal region of NodQ1 we localized an ATP-binding motif (GxxxxGK) and a PAPS motif [K(A/G) xxGxxx(N/E) $x(0$ or 1)FT] (Satishchandran et al., 1992). These consensus sequences have also been reported for NodQ of S. meliloti (Cervantes et al., 1989), R. tropici (FolchMallol et al., 1996; Laeremans et al., 1996), Rbizobium sp. N33 (Cloutier et al., 1996) and A. brasilense (Vieille \& Elmerich, 1990) and in CysNC of E. coli (Leyh et al., 1992). An alignment of nodQ-deduced amino acid sequences with elongation factors, as suggested by Cervantes et al. (1989), reveals for the BR816 NodQ1 sequence alignment conservation of an ITI motif, conserved among elongation factors (Kohno et al., 1986). Together, these data support the putative ATP sulphurylase and APS kinase activity of the enzymes encoded by the isolated BR816 nodP1Q1 genes. We could not find a putative nod box motif or significant homology to an E. coli consensus promoter in the $472 \mathrm{nt}$ sequence determined upstream of nodP1. No significant homology to other genes was found in this region, or in a $500 \mathrm{bp}$ region that was partially sequenced downstream of nodQ2. No stable transcription termination signals were found in the $3282 \mathrm{nt}$ sequenced. nodP1 and nodQ1 probably belong to the same transcription unit. However, the two genes could be translated independently, since both genes possess a putative ribosomebinding site. 
Table 2. Matrix showing interbacterial NodP and NodQ similarity/identity

Bacterial strains: BR, Rhizobium sp. BR816; N33, Rhizobium sp. N33; Sm, Sinorhizobium meliloti; $\mathrm{Rt}$, Rhizobium tropici; Ab, Azospirillum brasilense; Ec, Escherichia coli; see text for references. Numbers in parentheses refer to the number of amino acid residues of the respective NodP or NodQ proteins. In E. coli, the NodP and NodQ homologues are named CysD and CysNC, respectively.

\begin{tabular}{|lcccccc|}
\hline NodP: & BR (299) & N33 (301) & Sm (299) & Rt (299) & Ab (301) & Ec (302) \\
\hline BR & \multirow{2}{*}{$100 / 100$} & $86 / 76$ & $95 / 88$ & $91 / 79$ & $80 / 67$ & $82 / 66$ \\
N33 & & $100 / 100$ & $85 / 75$ & $84 / 69$ & $80 / 67$ & $81 / 69$ \\
Sm & & & $100 / 100$ & $92 / 78$ & $78 / 64$ & $81 / 68$ \\
Rt & & & & $100 / 100$ & $81 / 66$ & $81 / 62$ \\
Ab & & & & $100 / 100$ & $78 / 63$ \\
Ec & & & & & $100 / 100$ \\
\hline NodQ: & BR (633) & N33(646) & Sm (641) & Rt (632) & Ab $(\mathbf{6 2 0})$ & Ec $(\mathbf{6 7 7})$ \\
\hline BR & \multirow{2}{*}{$100 / 100$} & $80 / 67$ & $93 / 86$ & $88 / 78$ & $74 / 58$ & $69 / 52$ \\
N33 & & $100 / 100$ & $79 / 65$ & $79 / 63$ & $77 / 59$ & $72 / 55$ \\
Sm & & $100 / 100$ & $87 / 77$ & $74 / 57$ & $68 / 51$ \\
Rt & & & $100 / 100$ & $74 / 57$ & $69 / 50$ \\
Ab & & & & & $100 / 100$ & $70 / 53$ \\
Ec & & & & & & $100 / 100$ \\
\hline
\end{tabular}

\section{Mutation analysis of Rhizobium Sp. BR816 nodP1}

To investigate the biochemical role of the nodP1 gene on NF sulphation, we interrupted the BR816 nodP1 gene by inserting a $\mathrm{Km}$ resistance cassette in the $\mathrm{SacI}$ site (Fig. 3), and obtained CFNE205. This mutant (data not shown) did not have an altered NF TLC profile compared to that from the wild-type after induction with apigenin (Fig. 1a). Most likely, a second copy of nodPQ is responsible for the complementation of the nodP1 mutation, or the ORFs we characterized as nodPQ could be genes involved in providing precursors for the sulphurylation of amino acids such as cysteine or methionine, encoded by cysDNC in E. coli (Leyh et al., 1988), and are not involved in sulphation of Nod factors. Schwedock \& Long (1992) demonstrated that S. meliloti contained, in addition to the two nodPQ copies for NF sulphurylation, an additional sulphur activation locus for amino acid sulphation (called the saa locus). We can exclude the possibility that our identified ORFs are essential for amino acid sulphation since CFNE205 still grows on minimal medium and therefore is not an amino acid auxotroph. To provide evidence that the gene is transcribed, we ligated the promoter region of nodP1 (on a $1 \mathrm{~kb}$ XbaI-PstI fragment, Fig. 3) to a promoterless gusA gene from vector pRG960sd (Van den Eede et al., 1992) and introduced the construct into BR816. The reporter gene was expressed but no change in expression level was obtained upon addition of apigenin (data not shown). As for the nodPQ genes of S. meliloti, A. brasilense and $R$. tropici, BR816 nodP1Q1 expression is probably nod-box-independent and at a low constitutive level. Additional support for the Rhizobium sp. BR816 nodP1Q1 functionality was obtained after the introduction of pRKBRP1Q1 into CFNE200, a $R$. tropici
CFN299 NodP ${ }^{-}$mutant. TLC profiles of the Nod metabolites of the transconjugant strain showed the production of sulphated NFs (data not shown). We assumed that the non-detectable effect of the BR816 nodP1 mutation on NF sulphation was due to complementation by a second copy of nodPQ.

\section{Isolation and localization of Rhizobium sp. BR816 nodP2 and construction of a BR816 NodP1P2- mutant strain}

Since we were not able to isolate the $12 \mathrm{~kb}$ EcoRI fragment from the BR816 plasmid library by using the P1-P2 PCR probe, we applied another strategy to isolate at least parts of nodP2Q2 from the $12 \mathrm{~kb}$ EcoRI fragment. We designed the primer Q1C, based upon the sequence of nodP1Q1, downstream of the unique internal nodP1 SacI restriction site (Fig. 3). When the primer was used for PCR in combination with primer P1, using total DNA of BR816 or CFNE205 as the template, the following fragments were obtained. For PCR on BR816, a fragment of $950 \mathrm{bp}$ (for nodP1 and nodP2) was obtained. For PCR on CFNE205, a fragment of $950 \mathrm{bp}$ (for nodP2) and $2350 \mathrm{bp}$ (for mutated nodP1) was obtained. The $950 \mathrm{bp}$ PCR fragment, obtained using total DNA of CFNE205 as the template, was cloned and its physical map was determined (data not shown). We identified a unique $E c o R V$ restriction site in the middle of the $950 \mathrm{bp}$ fragment. Furthermore, a segment of $450 \mathrm{bp}$, between primers P1 and P2, was completely sequenced (data not shown). When comparing its deduced amino acid sequence with the GenBank sequences, highest homology was obtained to an internal S. meliloti NodP fragment. Compared to BR816 nodP1, this sequence showed a nucleotide iden- 
(a)

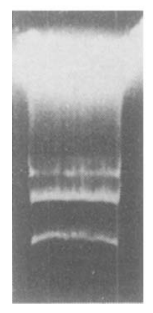

(b)

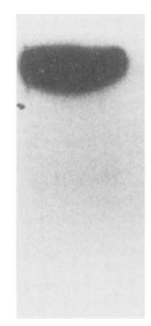

(c)

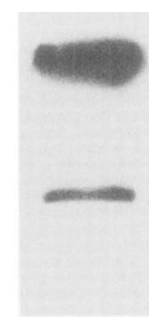

Fig. 4. Plasmid profile of Rhizobium sp. BR816 (a). Autoradiogram of a blotted plasmid profile of Rhizobium sp. BR816 CFNE205 (b) or CFNE207 (c) hybridized with the $\mathrm{Km}$ and the $\mathrm{Sp} / \mathrm{Sm}$ resistance cassettes, respectively.

tity of $85 \%$. The deduced amino acid sequence homology and identity compared to the corresponding part of BR816 nodP1 was $94 \%$ and $91 \%$, respectively. The $\mathrm{G}+\mathrm{C}$ content of the $450 \mathrm{bp}$ PCR fragment was $62 \mathrm{~mol} \%$, similar to the BR 816 nodP1Q1 G + C content but higher than the $\mathrm{G}+\mathrm{C}$ content of $R$. tropici nodulation genes (Laeremans et al., 1996). BR816 nodP2Q2 also possesses an overlap of 1 bp between the stop codon of nodP and the start codon of nodQ. To make sure that the fragment we isolated was localized on the $12 \mathrm{~kb}$ EcoRI DNA segment, we used the 950 bp PCR fragment from CFNE205 as a probe to hybridize against EcoRIdigested BR816 total DNA. Two hybridization bands were obtained identical to those obtained with the $450 \mathrm{bp}$ PCR fragment using primers P1 and P2 with BR816 total DNA as the template (data not shown), but the $12 \mathrm{~kb}$ EcoRI fragment hybridized more strongly. Previously, van Rhijn et al. (1993) demonstrated the presence of two plasmids in strain BR816. By using the method described by Géniaux et al. (1995), we detected an additional plasmid (which we here call the megaplasmid) with a higher molecular mass. Using an internal nodP1 or the nodP2Q2 PCR fragment as a probe against a blot of a BR816 Eckhardt profile (Fig. 4a), we localized nodP1 on the megaplasmid and nodP2 on the symbiotic plasmid, pSym (data not shown).

To investigate the effect of a double nodP1P2 mutation in BR816 on the NF sulphation process, we inserted a $\mathrm{Sp} / \mathrm{Sm}$ resistance cassette into a BR816 nodP2 EcoRV restriction site, positioned a few base pairs downstream of the primer P2 annealing site, and constructed the double nodP1P2 mutant strain (CFNE207) by double homologous recombination in CFNE205. CFNE207 did not require additional cysteine in its growth medium to survive. To confirm the localization of both BR816 nodP copies, we hybridized a Southern blot of an Eckhardt profile against the $\mathrm{Km}$ and $\mathrm{Sp} / \mathrm{Sm}$ resistance cassettes. The $\mathrm{Km}$ cassette only hybridized with the megaplasmid (Fig. 4b) whereas the Sp/Sm probe only hybridized with the pSym (Fig. 4c), indisputably showing that, as in $S$. meliloti, the copies are localized on different plasmids.

Surprisingly, no differences were found between the CFNE207 and the BR816 NF TLC profiles (Fig. 1). Subsequent plant inoculation experiments with the common bean cultivar N-8-116 did not reveal statistically significant differences in nodule numbers or in nodule morphology between CFNE207 and the wildtype BR 816 strain under any of the three different plant growth conditions tested (data not shown). In $S$. meliloti, mutations in the carboxy-terminal halves of NodP or NodQ still showed wild-type nodulation phenotypes (Schwedock \& Long, 1989). A similar situation might have occurred for the Rhizobium sp. BR816 nodP2 mutant since the antibiotic resistance cassette is inserted in the $3^{\prime}$ region of nodP2. In the event that BR816 nodP2 and nodQ2 do not belong to the same operon and the mutation in nodP2 provokes a truncated but active ATP sulphurylase not affecting a putative nodP internal nodQ promoter sequence, it is possible that the NF sulphur activation complex is still active, although the amount of PAPS for NF sulphation would be expected to be lower (as is the case for $S$. meliloti nodQ1 or nodQ2 single mutants), since the expressed nodP1 is effectively mutated. Roche et al. (1991) demonstrated by TLC and HPLC that in S. meliloti both nodPQ copies approximately equally contributed to NF sulphation. Additionally, we constructed a distinct BR816 nodQ2 deletion mutant by exchange of a nodQ2 internal SalI fragment for the $\mathrm{Sp} / \mathrm{Sm}$ resistance cassette, obtaining CFNE206. As for CFNE205 and CFNE207, the CFNE206 TLC profile did not show any detectable differences to that from the wild-type strain (data not shown). Cosmid BRVIID9, containing the BR816 nodP2Q2 genes, was mated into CFNE200. The transconjugant strain produced sulphated NFs (data not shown). A Southern hybridization of EcoRI-digested BRVIID9 DNA against a heterologous nodH probe revealed the presence of a nodH homologous region on the $12 \mathrm{~kb}$ EcoRI fragment that also contains the nodP2Q2 genes (data not shown). On the other hand, if BR816 nodP2 and nodQ2 do belong to the same transcriptional unit, the mutation in nodP2, due to its polarity, should affect nodQ2, assuming that the $\mathrm{Sp} / \mathrm{Sm}$ resistance cassette does not contain a promoter recognized by BR816, as is the case for some Tn5 insertions in S. meliloti genes (Corbin et al., 1983). As a consequence, no activated sulphur source provided by the BR816 nodPQ genes is present, if the two nodPQ copies of BR816 are the only genes responsible for NF sulphation. We therefore concluded that a third locus, encoding enzymes for sulphur activation and at least partially providing an activated sulphate source for NF sulphation, is likely to be present in BR816.

\section{Localization of a third PAPS-producing locus}

Previously, we isolated the R. tropici CFN299 cysDNC homologues, distinct from the nodHPQ NF sulphation locus (our unpublished results; Laeremans et al., 1996). The cosmid that carries these genes also contains sequences with significant homology to E. coli cysH, encoding a PAPS reductase in its amino acid sulphation pathway. This gene does not have a homologous counterpart in the NF sulphation pathway. When we probed Southern blots of EcoRI-digested total DNA of 
strain BR816 under low-stringency conditions against the $R$. tropici CFN299 cysDN, the $4.3 \mathrm{~kb}$ EcoRI fragment hybridized, with some signal also observed on the $12 \mathrm{~kb}$ EcoRI fragment. In contrast, with the R. tropici cys $H$ homologue as a probe only the $4.3 \mathrm{~kb}$ EcoRI fragment was revealed (data not shown). From the three hybridizing fragments in Fig. 2, the $12 \mathrm{~kb}$ and $2.3 \mathrm{~kb}$ fragments showed strongest hybridization with a nodPQ probe, whilst the $4.3 \mathrm{~kb}$ fragment showed strongest hybridization with an internal fragment of $c y s H$ and cys D genes (T. Laeremans and others, unpublished).

S. meliloti also possesses two sulphur activation pathways: a symbiotic pathway (encoded by the nodPQ genes, present in two copies) and a housekeeping pathway. The genes encoding enzymes for the latter pathway are localized at the saa locus (Schwedock $\&$ Long, 1992), having functional homology to the $E$. coli $c y s D N C$ genes, necessary for the production of an activated sulphate donor (PAPS) in the amino acid sulphation pathway (Kredich, 1987). Apparently, both nodPQ and $c y s D N C$ (or saa in the case of $S$. meliloti) are responsible for the production of PAPS, but the NF sulphotransferase NodH cannot use the sulphate precursor provided by the saa locus since a $S$. meliloti double nodQ1Q2 mutant produces non-sulphated NFs (Roche et al., 1991). Why do two sulphate activation systems exist in rhizobia that produce sulphated NFs? Roche et al. (1991) hypothesized that an additional sulphate activation pathway is required for efficient and energy-saving Nod factor sulphation since nodPQ delivers an extra supply of PAPS at the appropriate time and cellular compartment. The 'housekeeping' PAPS is probably generated in the cytosol while the 'symbiotic' PAPS is produced in the periplasmic space or in the membrane system and no detectable transport of PAPS from the household to the symbiotic pathway occurs. Otherwise, the in vivo formation of the NF sulphurylation complex associating the ATP sulphurylase, the APS kinase and the sulphotransferase, wherein the intermediates are directly transferred to the next enzyme (Schwedock et al., 1994), could explain why in S. meliloti a mutation in the NF sulphation locus is not complemented by the amino acid sulphate activation pathway. Similarly, in the E. coli sulphur activation pathway, a PAPS synthetase complex is formed in which the intermediate APS is directly transferred between the gene products of $c y s D N$ and $c y s C$ (Leyh et al., 1988). The metabolic channelling of substrates and/or a different localization of the enzymes of both sulphur activation pathways, and the inability to transport PAPS from the cytosol to the NF sulphation site, could explain why in S. meliloti or in R. tropici CFN299 no complementation of mutations in NF sulphation precursor genes by the saa locus occurs. On the contrary, in Rhizobium sp. BR816, NodP, NodQ and NodH might not associate into a NF sulphation complex, leaving the possibility that 'household' PAPS could enter the NF sulphation pathway. Additionally, the BR816 NF sulphation machinery could be localized in the cytosol. Complementation of mutations in nodulation genes by housekeeping genes is not a new phenomenon. In $S$. meliloti (Baev et al., 1991) and R. leguminosarum (Marie et al., 1992), NodM, the enzyme for production of $\mathrm{D}-$ glucosamine synthetase, a precursor for the NF backbone, has a household homologue, GlmS. Both enzymes can provide NF glucosamine precursors. In Azorhizobium caulinodans, a second fucosyltransferase, not encoded by nod $Z$, is also present since a mutation in nod $Z$ does not completely abolish the existence of fucosylated NFs (Mergaert et al., 1996). Even for nodulation proteins involved in the export of the nodulation factor encoded by nodIJ, secondary proteins may exist with the same function, since nodl or nodJ mutants of $R$. leguminosarum still export small amounts of NFs (Spaink et al., 1995).

In R. tropici, Poupot et al. (1995b) suggested a link between the symbiotic sulphate activation pathway and NF methylation. By introducing the $S$. meliloti nodPQ genes into the wild-type $R$. tropici, apart from sulphating all $R$. tropici NFs, the rate of the $R$. tropici NF $N$-methylation decreased. However, it cannot be excluded that such a link may also exist between the $R$. tropici household sulphate activation and NF methylation pathway. A R. tropici strain mutated in nodP lacks the symbiotic PAPS form (since its NFs are no longer sulphated) and still nodulates common bean (Laeremans et al., 1996). Since methylation of NFs is required for nodulation of bean (Waelkens et al., 1995), and is dependent on the presence of PAPS, it can be suggested that the PAPS source for NF methylation might come from the household sulphate activation system. Thus, for NF production, nodulation genes are indispensable, but at least in some strains household genes can take over their functions, possibly even in the Nod factor sulphation pathway. Some important questions still remain unanswered. Why does complementation between the symbiotic and household sulphate activation systems not occur in both directions? When $S$. meliloti nodPQ genes are expressed at a high level, they can restore E. coli cysteine auxotrophs (Schwedock et al., 1994). Does a unidirectional cellular PAPS pump system exist in S. meliloti? Why do antibodies against E. coli CysC only react to NodQ and not to protein products of the saa locus from S. meliloti (Schwedock et al., 1994)? In conclusion, this report provides the first evidence that a household locus can complement, at least partially but to a significant extent, mutations in genes responsible for NF sulphation. We are currently investigating the role of the R. tropici saa locus on NF sulphation and methylation.

\section{ACKNOWLEDGEMENTS}

This work was financially supported by a VLIR-ABOS grant from the Belgian Government. We thank P. Mavingui and $M$. Hynes for critically reading the manuscript, and J. CaballeroMellado for helpful tips.

\section{REFERENCES}

Baev, N., Endre, G., Petrovics, G., Banfalvi, Z. \& Kondorosi, A. (1991). Six nodulation genes of nod box locus 4 in Rhizobium 
meliloti are involved in nodulation signal production: nodM encodes D-glucosamine synthetase. Mol Gen Genet 228, 113-124.

Beringer, J. E. (1974). R-factor transfer in Rhizobium leguminosarum. J Gen Microbiol 84, 188-198.

Carlson, R. W., Sanjuan, J., Bhat, U. R. and 7 other authors (1993). The structures and biological activities of the lipo-oligosaccharide nodulation signals produced by type I and II strains of Bradyrhizobium japonicum. J Biol Chem 268, 18372-18381.

Cervantes, E., Sharma, S. B., Maillet, F., Vasse, J., Truchet, G. \& Rosenberg, C. (1989). The Rhizobium meliloti host range nodQ gene encodes a protein which shares homology with translation elongation and initiation factors. Mol Microbiol 3, 745-755.

Cloutier, J., Laberge, S., Castonguay, Y. \& Antoun, H. (1996). Characterization and mutational analysis of nodHPQ genes of Rhizobium strain N33. Mol Plant-Microbe Interact 9, 720-728.

Corbin, D., Barran, L. \& Ditta, G. (1983). Organization and expression of Rhizobium meliloti nitrogen fixation genes. Proc Natl Acad Sci USA 80, 3005-3009.

Debellé, F. \& Sharma, S. B. (1986). Nucleotide sequence of Rhizobium meliloti RCR2011 genes involved in host specificity of nodulation. Nucleic Acids Res 14, 7453-7472.

Debellé, F., Plazanet, C., Roche, P., Pujol, C., Savagnac, A., Rosenberg, C., Promé, J.-C. \& Dénarié, J. (1996). The NodA proteins of Rbizobium meliloti and Rhizobium tropici specify the $\mathrm{N}$-acylation of Nod factors by different fatty acids. Mol Microbiol 22, 303-314.

Dénarié, J., Debellé, F. \& Promé, J.-C. (1996). Rhizobium lipochitooligosaccharide nodulation factors: signalling molecules mediating recognition and morphogenesis. Annu Rev Biochem 65, 503-53.5.

Dever, E. T., Glynias, M. J. \& Merrick, W. C. (1987). GTP-binding domain: three consensus sequence elements with distinct spacing. Proc Natl Acad Sci USA 84, 1814-1818.

Downie, J. A. (1989). The nodL gene from Rhizobium leguminosarum is homologous to transacetylases encoded by lacA and cysE. Mol Microbiol 3, 1649-1651.

Ehrhardt, D. W., Atkinson, E. M., Faull, K. F., Freedberg, D. I., Sutherlin, D. P., Armstrong, R. \& Long, S. R. (1995). In vitro sulfotransferase activity of $\mathrm{NodH}$, a nodulation protein of Rhizobium meliloti required for host-specific nodulation. J Bacteriol 177, 6237-6245.

Faucher, C., Maillet, F., Vasse, J., Rosenberg, C., van Brussel, A. A. N., Truchet, G. \& Dénarié, J. (1988). Rhizobium meliloti host range $\operatorname{nodH}$ gene determines production of an alfalfa-specific extracellular signal. J Bacteriol 170, 5489-5499.

Folch-Mallol, J. L., Marroquí, S., Sousa, C. and 9 other authors (1996). Characterization of Rhizobium tropici CIAT899 nodulation factors: the role of nodH and nodPQ genes in their sulfation. Mol Plant-Microbe Interact 9, 151-163.

Friedman, A. M., Long, S. R., Brown, S. E., Buikema, W. J. \& Ausubel, F. M. (1982). Construction of a broad host range cosmid cloning vector and its use in the genetic analysis of Rbizobium mutants. Gene 18, 289-296.

Geelen, D., Mergaert, P., Geremia, R. A., Goormachtig, S., Van Montagu, M. \& Holsters, M. (1993). Identification of nodSUIJ genes in Nod locus 1 of Azorbizobium caulinodans: evidence that nodS encodes a methyltransferase involved in Nod factor modification. Mol Microbiol 9, 145-154.

Géniaux, E., Flores, M., Palacios, R. \& Martínez, E. (1995). Presence of megaplasmids in Rhizobium tropici and further evidence of differences between the two $R$. tropici subtypes. Int $J$ Syst Microbiol 45, 392-394.
Hernández-Lucas, I., Segovia, L., Martínez-Romero, E. \& Pueppke, S. G. (1995). Phylogenetic relationships and host range of $R h i-$ zobium spp. that nodulate Phaseolus vulgaris L. Appl Environ Microbiol 61, 2775-2779.

Hungria, M., Franco, A. A. \& Sprent, J. I. (1993). New sources of high-temperature tolerant rhizobia for Phaseolus vulgaris L. Plant Soil 149, 103-109.

Jabbouri, S., Fellay, R., Talmont, F., Kamalaprija, P., Burger, U., Relic, B., Promé, J.-C. \& Broughton, W. J. (1995). Involvement of $\operatorname{nod} S$ in $\mathrm{N}$-methylation and nodU in 6-O-carbamoylation of Rhizobium sp. NGR234 Nod factors. J Biol Chem 270, 2296822973.

Jones, J. D. G. \& Gutterson, N. (1987). An efficient mobilizable cosmid vector, pRK7813, and its use in a rapid method for marker exchange in Pseudomonas fluorescens strain HV37a. Gene 61, 299-306.

Knauf, V. C. \& Nester, E. W. (1982). A cosmid clone bank of an Agrobacterium Ti plasmid. Plasmid 8, 45-54.

Kohno, K., Uchida, T., Ohkubo, H., Nakanishi, S., Nakanishi, T., Fukui, T., Ohtsuka, E., Ikehara, M. \& Okada, Y. (1986). Amino acid sequence of mammalian elongation factor 2 deduced from the cDNA sequence: homology with GTP-binding sites. Proc Natl Acad Sci USA 83, 4978-4982.

Kondorosi, A. (1991). Regulation of nodulation genes in rhizobia. In Molecular Signals in Plant-Microbe Communication, pp. 325-340. Edited by D. P. S. Verma. Boca Raton, FL: CRC Press.

Kredich, N. M. (1987). Biosynthesis of cysteine. In Escherichia coli and Salmonella: Cellular and Molecular Biology, pp. 419-427. Edited by F. C. Neidhardt and others. Washington, DC: American Society for Microbiology.

Laeremans, T., Caluwaerts, I., Verreth, C., Rogel, M. A., Vanderleyden, J. \& Martínez-Romero, E. (1996). Isolation and characterization of the Rhizobium tropici Nod factor sulfation genes. Mol Plant-Microbe Interact 9, 492-500.

Lerouge, P., Roche, P., Faucher, C., Maillet, F., Truchet, G., Promé, J.-C. \& Dénarié, J. (1990). Symbiotic host-specificity of R hizobium meliloti is determined by a sulphated and acylated glucosamine oligosaccharide signal. Nature 344, 781-784.

Leyh, T. S., Taylor, J. C. \& Markham, G. D. (1988). The sulfate activation locus of Escherichia coli K-12: cloning, genetic, and enzymic characterization. J Biol Chem 263, 2409-2416.

Leyh, T. S., Vogt, T. F. \& Suo, Y. (1992). The DNA sequence of the sulfate activation locus from Escherichia coli K-12. J Biol Chem 267, 10405-10410.

Marie, C., Barny, M.-A. \& Downie, J.A. (1992). Rbizobium leguminosarum has two glucosamine synthases, GlmS and NodM, required for nodulation and development of nitrogenfixing nodules. Mol Microbiol 6, 843-851.

Marsh, J. L., Erfle, M. \& Wykes, E. J. (1984). The pIC plasmids and phage vectors with versatile cloning sites for recombinant selection by insertional inactivation. Gene 32, 481-485.

Martínez, E., Pardo, M. A., Palacios, R. \& Cevallos, M. A. (1985). Reiteration of nitrogen fixation gene sequences and specificity of Rbizobium in nodulation and nitrogen fixation in Phaseolus vulgaris. J Gen Microbiol 131, 1779-1786.

Mergaert, P., Van Montagu, M., Promé, J.-C. \& Holsters, M. (1993). Three unusual modifications, a D-arabinosyl, a N-methyl, and a carbamoyl group are present on the Nod factors of Azorbizobium caulinodans strain ORS571. Proc Natl Acad Sci USA 90, 1551-1555.

Mergaert, P., D’Haeze, W., Fernández-López, M., Geelen, D., Goethals, K., Promé, J.-C., Van Montagu, M. \& Holsters, M. 
(1996). Fucosylation and arabinosylation of Nod factors in Azorbizobium caulinodans: involvement of nolK, nodZ as well as noe C and/or downstream genes. Mol Microbiol 21, 409-419.

Mulligan, J. T. \& Long, S.R. (1985). Induction of Rhizobium meliloti nodC expression by plant exudate requires nodD. Proc Natl Acad Sci USA 82, 6609-6613.

Murillo, J., Shen, H., Gerhold, D., Sharma, A., Cooksey, D. A. \& Keen, N. T. (1994). Characterization of pPT23B, the plasmid involved in syringolide production by Pseudomonas syringae pv. tomato PT23. Plasmid 31, 275-287.

Mylona, P., Pawlowski, K. \& Bisseling, T. (1995). Symbiotic nitrogen fixation. Plant Cell 7, 869-885.

Norrander, J., Kempe, T. \& Messing, J. (1983). Construction of improved M13 vectors using oligodeoxynucleotide-directed mutagenesis. Gene 26, 101-106.

Orgambide, G. G., Lee, J., Hollingsworth, R. I. \& Dazzo, F. B. (1995). Structurally diverse chitolipooligosaccharide Nod factors accumulate primarily in membranes of wild-type Rhizobium leguminosarum biovar trifolii. Biochemistry 34, 3832-3840.

Petersen, G. B., Stockwell, P. A. \& Hill, D. F. (1988). Messenger RNA recognition in Escherichia coli: a possible second site of interaction with $16 \mathrm{~S}$ ribosomal RNA. EMBO J 7, 3957-3962.

Poupot, R., Martínez-Romero, E. \& Promé, J.-C. (1993). Nodulation factors from Rhizobium tropici are sulfated or nonsulfated chitopentasaccharides containing an $\mathrm{N}$-methyl- $\mathrm{N}$-acylglucosaminyl terminus. Biochemistry 32, 10430-10435.

Poupot, R., Martínez-Romero, E., Gautier, N. \& Promé, J.-C. (1995a). Wild-type Rhizobium etli, a bean symbiont, produces acetyl-fucosylated, $N$-methylated, and carbamoylated nodulation factors. J Biol Chem 270, 6050-6055.

Poupot, R., Martínez-Romero, E., Maillet, F. \& Promé, J.-C. (1995b). Rhizobium tropici nodulation factor sulfation is limited by the quantity of activated form of sulfate. FEBS Lett 368, 536-540.

Price, N. P. J., Relic, B., Talmont, F. and 7 other authors (1992). Broad-host-range Rhizobium species strain NGR234 secretes a family of carbamoylated, and fucosylated, nodulation signals that are O-acetylated or sulphated. Mol Microbiol 6, 3575-3584.

Quandt, J. \& Hynes, M. F. (1993). Versatile suicide vectors which allow direct selection for gene replacement in Gram-negative bacteria. Gene 127, 15-21.

van Rhijn, P. J. S., Feys, B., Verreth, C. \& Vanderleyden, J. (1993). Multiple copies of nodD in Rbizobium tropici CIAT899 and BR816, J Bacteriol 175, 438-447.

van Rhijn, P., Luyten, E., Vlassak, K. \& Vanderleyden, J. (1996). Isolation and characterization of a pSym locus of Rhizobium sp. BR816 that extends nodulation ability of narrow host range Phaseolus vulgaris symbionts to Leucaena leucocephala. Mol Plant-Microbe Interact 9, 74-77.

Ritsema, T., Wijfjes, A. H. M., Lugtenberg, B. J. J. \& Spaink, H. P. (1996). Rhizobium nodulation protein NodA is a host-specific determinant of the transfer of fatty acids in Nod factor biosynthesis. Mol Gen Genet 251, 44-51.

Roche, P., Debellé, F., Maillet, F., Lerouge, P., Faucher, C., Truchet, G., Dénarié, J. \& Promé, J.-C. (1991). Molecular basis of symbiotic host specificity in Rhizobium meliloti: nodH and nodPQ genes encode the sulfation of lipo-oligosaccharide signals. Cell 67, 1131-1143.

Sanjuan, J., Carlson, R. W., Spaink, H. P., Bhat, U. R., Barbour, W. M., Glushka, J. \& Stacey, G. (1992). A 2-O-methylfucose moiety is present in the lipo-oligosaccharide nodulation signal of Bradyrhizobium japonicum. Proc Natl Acad Sci USA 89, 8789-8793.
Sambrook, J., Fritsch, E. F. \& Maniatis, T. (1989). Molecular Cloning: a Laboratory Manual, 2nd edn. Cold Spring Harbor, NY: Cold Spring Harbor Laboratory.

Satishchandran, C., Hickman, Y. N. \& Markham, G. D. (1992). Characterization of the phosphorylated enzyme intermediate formed in the adenosine $5^{\prime}$-phosphosulfate kinase reaction. Biochemistry 31, 11684-11688.

Schultze, M., Kondorosi, E. \& Kondorosi, A. (1993). The sulfate group on the reducing end protects Nod signals of Rhizobium meliloti against hydrolysis by medicago chitinases. In New Horizons in Nitrogen Fixation, pp. 159-164. Edited by R. Palacios, J. Mora \& W. E. Newton. Dordrecht: Kluwer.

Schultze, M., Staehelin, C., Röhrig, H., John, M., Schmidt, J., Kondorosi, E., Schell, J. \& Kondorosi, A. (1995). In vitro sulfotransferase activity of Rhizobium meliloti NodH protein: lipochitooligosaccharide nodulation signals are sulfated after synthesis of the core structure. Proc Natl Acad Sci USA 92, 2706-2709.

Schwedock, J. \& Long, S.R. (1989). Nucleotide sequence and protein products of two new nodulation genes of Rhizobium meliloti, nodP and nodQ. Mol Plant-Microbe Interact 2, 181-194.

Schwedock, J. \& Long, S. R. (1990). ATP sulphurylase activity of the nodP and nodQ gene products of Rhizobium meliloti. Nature 348, 644-647.

Schwedock, J. S. \& Long, S. R. (1992). Rhizobium meliloti genes involved in sulfate activation: the two copies of nodPQ and a new locus, saa. Genetics 132, 899-909.

Schwedock, J. S., Liu, C., Leyh, T. S. \& Long, S. R. (1994). Rhizobium meliloti NodP and NodQ form a multifunctional sulfate-activating complex requiring GTP for activity. $J$ Bacteriol 176, 7055-7064.

Spaink, H. P. (1996). Regulation of plant morphogenesis by lipochitin oligosaccharides. Crit Rev Plant Sci 15, 559-582.

Spaink, H.P., Wijfjes, A. H. M. \& Lugtenberg, B. J. J. (1995). Rhizobium NodI and NodJ proteins play a role in the efficiency of secretion of lipochitin oligosaccharides. J Bacteriol 177, 62766281.

Staehelin, C., Schultze, M., Kondorosi, E., Mellor, R. B., Boller, T. \& Kondorosi, A. (1994). Structural modifications in R hizobium meliloti Nod factors influence their stability against hydrolysis by root chitinases. Plant J 5, 319-330.

Truchet, G., Roche, P., Lerouge, P., Vasse, J., Camut, S., de Billy, F., Promé, J.-C. \& Dénarié, J. (1991). Sulphated lipo-oligosaccharide signals of Rhizobium meliloti elicit root nodule organogenesis in alfalfa. Nature 351, 670-673.

Van den Eede, G., Deblaere, R., Goethals, K., Van Montagu, M. \& Holsters, M. (1992). Broad host range and promoter selection vectors for bacteria that interact with plants. Mol Plant-Microbe Interact 5, 228-234.

Vieille, C. \& Elmerich, C. (1990). Characterization of two Azospirillum brasilense Sp7 plasmid genes homologous to Rhizobium meliloti nodPQ, Mol Plant-Microbe Interact 3, 389-400.

Waelkens, F., Voets, T., Vlassak, K., Vanderleyden, J. \& van Rhijn, P. (1995). The nodS gene of Rhizobium tropici strain CIAT899 is necessary for nodulation on Phaseolus vulgaris and on Leucaena leucocephala. Mol Plant-Microbe Interact 8, 147-154.

Received 6 May 1997; revised 18 August 1997; accepted 8 September 1997. 